DOI: $10.31558 / 2308-1902.2018 .26 .3$

УДК 821.161 .2

Ірина ЗЕЛЕНЕНЬКА, кандидат філологічних наук, старший викладач, ВДПУ імені М. Коцюбинського

Віктор КРУПКА, кандидат філологічних наук, старший викладач, ВДПУ імені М. Коцюбинського

\title{
ВАСИЛЬ СТУС, ТАРАС МЕЛЬНИЧУК, ВОЛОДИМИР ЗАБАШТАНСЬКИЙ ТА ШЕВЧЕНКІВ КОСМОС УКРАЇНИ
}

У статті йдеться про образ-символ України у віршах дисидентів Василя Стуса, Тараса Мельничука і «традиційника» Володимира Забаштанського. Вітчизна перебувала в центрі художньої світобудови цих письменників, почасти завдяки своєрідному лицарському культу навколо неї, культивованому в 60-х pp. ХХ ст. Василь Стус і Володимир Забаштанський безпосередньо причетні до Поділля (це їхня мала батьківщина), Тарас Мельничук відбував у Вінниці перший термін ув'язнення (задокументовано не як політичний, а як побутовий). Для цих поетів тема України в осмисленні страдництва, жертовності й Шевченкових пророцьких осяянь стала домінантною.

Ключові слова: образ-символ, метафора, екзистенція, герметичність, рух опору, дисиденти.

Україна як образ-символ часто функціонує у віршах у формі «ідеї для себе» [6, с. 166], пошуку свого світу. Це пов'язано з тим, що Батьківщина перебувала у центрі художньої світобудови багатьох мистців, чия творчість припала на 1960-80-і pp. ХX століття, почасти завдяки своєрідному лицарському культу України (один із його основоположників - Василь Симоненко). Серед тих, хто причетний до Поділля, у цій парадигмі, - Василь Стус (в'язень сумління, дисидент, родом із Рахнівки Гайсинського району), Володимир Забаштанський (браїлівець, скалічений внаслідок нещасного випадку) і Тарас Мельничук (гуцул, який працював на Вінниччині й відбував перший термін у Вінниці). Для них тема України в осмисленні страдництва, жертовності й Шевченкових пророцьких осяянь стала провідною, що й зумовило фокус нашого дослідження, адже в компаративному зрізі це питання не пыднымалося.

У 1984 році Василь Стус написав у листі до рідних про ідею збірки під назвою «Страсті по Вітчизні....» [5, т. 6, с. 479], тому в його медитативних віршах немає декларативності, прямолінійності проявлення почуттів; 
превалюють твори без трибунних назв, властивих Василеві Симоненку («Україні», «Русь», «Україно, п’ю твої зіниці!» та ін.). Звернімо увагу на модерні назви творів Василя Стуса («Вереснева земля», «У цьому полі, синьому, як льон...»), Тараса Мельничука («Земля навколішках до паркану...», «Коли атом говорить про м'яту...»); у Володимира Забаштанського - все ж таки Симоненкові акценти («Колядники», «Рідна мова»), пов’язані з символікою України, у яких макро переосмислено через мікро, загальне через часткове, величне через просте й доступне.

Часто акцент у віршах згаданих поетів припадав на семантику родинності й материнства, зокрема на етносемантику: «Земля сп'яніла - під крилом / Гойднулась хвильно, / Пливе, втікає і зорить / I назирці тримає / Тебе, мов сина... / Земле! Краю мій! / У сизуватій млі, / Там, де розтав вишиваний рукав, / Лишилось серце...» («Мандри», Василь Стус) [10, с. 15]; «Сьогодні шлюб сонця і бджоли / хліб у мережаній сорочці / і під стріхою ластівка будує собі маленьку Україну» («Материнство», Тарас Мельничук) [6, II, с. 156], «Україно, молюся за тебе, Як за матір гріховно-святу...» («Молитва», Володимир Забаштанський) [2, с.6]. Особливо виразним є патріархальний образ-символ українського роду, втілений у спогаді про діда, до котрого вчащали колядники, доки не виросли: «Ми знаємо - нема у діда хліба. / А каганець сумний у шибі кліпа...», «Та дід, зворушений, виносить чемно / В полумиску картоплю нам печену...» («Колядники», Володимир Забаштанський) [2, с. 136].

Враження материнства рідної землі, як правило, підсилювали неоромантичні й необарокові пейзажно-країнознавчі замальовки, втиснені в межі медитацій: «Полтавщино! Я пізнаю твій голос, / Коли кують немовкні зозулі / I в колос пророста пташиний щебет, / Що будять тишу і дають відчути / Ïї глуху, аж сизу, глибину» (Василь Стус) [8, с. 23], «Вкраїна пахне вишняком, / I дзбаном сонця п’ють смереки / Туману біле молоко. / Висять тут роси, як суниці...» («Гуцульщина», Тарас Мельничук) [6, I, с. 90]. У віршах Володимира Забаштанського васальні пейзажно-країнознавчі мотиви вплітаються в 
домінантні декларативно-патріотичні: «Запеклись на морозах душі / Мого болю калинові грона» («Тільки б...»), «За блакить твого вічного неба / I за ниву твою золоту...» («Молитва») [2, с. 6].

Суб'єкт медитативного мовлення у значній кількості творів поетівдисидентів Василя Стуса й Тараса Мельничука - ліричний герой-в'язень, бунтар або ж герой-лідер; назвемо тут, для прикладу, «Останній лист Довженка», «Сковорода. Хвилеві трени», «Голос Сковороди», «Дума Сковороди», «Тарас на засланні», «Костомаров у Саратові», «Гайдамацьке» Василя Стуса, «Вирубали турки Дунай...», «В полумиску відпочиває козак Мамай», «Тут Сагайдачний...», «Свідчення останнього гетьмана» Тараса Мельничука. У віршах Володимира Забаштанського інтонує звіряннями сліпий учень-співець великого Тараса Шевченка: «За плечима стою в Кобзаря...» («Зоря») [4, с. 256]. Чи не найпромовистіше подібне виписано в мініатюрі-зверненні до сестри, що подається в дусі апеляцій Тараса Шевченка до сестер: «А я радію, сестро, в темнині - / Комусь на світі легше, ніж мені» [8, с. 246]. Володимир Забаштанський інтуїтивно проектував свого ліричного героя як юродивого, але не як відвертого прихильника андеграунду й дисидентства: «Пішов за овид поїзд мій сторчма / Нікого на пероні вже нема. / Нікого - і сльозам немає стриму» («Гудків не чутно вже...») [8, с. 246].

Поети 3-посеред шістдесятих років почали активно звертатися до алюзії (натяк на факт), обминаючи цензуру, торкалися символіки важливих для українського державотворення подій, на відміну від інших своїх сучасників, вірші яких були лекально дотичними до легенд навколо постатей світової історії та культури («Коли помер кривавий Торквемада» Дмитра Павличка, «Курдському братові» Василя Симоненка, «Іма Сумак» Ліни Костенко та ін.), тому численні версифікації навколо в'язня імперії Тараса Шевченка й навколо пантеону героїв-мучеників визвольної боротьби в контексті творчості Василя Стуса, Тараса Мельничука, Володимира Забаштанського, які витримали межові випробування, $є$ виправданими й нетрибунними 
(рупорну позірність часто подибуємо в напівпубліцистичних строфах шістдесятників-офіційників).

За провідною темою любові до Батьківщини й синівського обов'язку перед нею поети показали трагедію мистця під пресом тоталітаризму, часто явленого й осмисленого демонологічно («Моя Україна забула сміятись...» Василя Стуса, «Рухаюсь мало...» Тараса Мельничука); у Володимира Забаштанського все це герметизовано і приховано за експериментами: «3 тихим болем своїм закімнатився» («Снага слова»). «Останній лист Довженка» Василя Стуса перегукується з Шевченковим «Заповітом», проте Дніпро в «Кобзарі»«ревучий», у Василя Стуса - німий, екзальтований, передапокаліпсичний: «Нехай гризуть дніпрові гострі кручі // моє зболіле серце» («Останній лист Довженка») [7, с. 84]. У притчевій візії Тараса Мельничука йдеться про те, що його ліричний герой - риба з «гачком у губі» (себто поет - в'язень СРСР); ідея високо-символічна: «поети / бранці й ланці / і вовкулаки й сибіряки / i сніговіїхуртовини (я аж заплакав) / босі з України у вікно дивляться / облизуючи місяць» [4, II, с. 75]; до речі, Тарас Мельничук частіше згадував у віршах Дністер і Дунай, аніж Дніпро. Володимир Забаштанський бачив трагедію українців у невикоріненому захланстві: «То лаври хапав горлодер / За глум, за ненавидь, за кпини. / Чому б жебракові тепер / Не дать за любов до Вкраїни?» («Лаври») [1, с. 48].

Поміж історичних персонажів, згаданих у віршах Василя Стуса, Тараса Мельничука, Володимира Забаштанського, особлива роль належить Тарасові Шевченку як сакралізованому захисникові України; цей образ невіддільний від суспільно-політичної картини світу, яку попри цензуру транслювали свідомі поети підрадянської України. Навіть там, де Тарас Шевченко не $є$ героєм поезій, виражає чи дублює авторське «я»: «Тарасові провісні птиці слова шугають над Дніпром» («Сто років як сконала Січ» Василя Стуса) [7, с. 81], «Червоніє світ, як бурякова терка... / А Тарас Шевченко.../ Що він заповів?» («Камениця дивиться в люстерко...» Тараса Мельничука) [6, II, с. 165]. Стусова лінійна позиція «Калнишевський - Дніпро» змінюється 
Мельничуковою позицією «Хмельницький - Дунай»: «Київ з Богданом п’єгуляє / та у червоний дзбан Дунай ховає...» («Голод») [4, II, с. 78].

Володимир Забаштанський, у ключі традиційної манери (як і неоромантик Василь Симоненко, як і свого часу романтик Тарас Шевченко) насичує свої катрени природними, а тому зрозумілими для читача-слов'янина образами України (рідної землі, матері), апеляціями до Тараса як до батька нації та вселенської правди: «Добре, батьку, дуже добре стало / Поле наше й ми вже не раби. / Буде хліб і, звісно, буде сало, / Чесно лиш на полі тім роби» («Треба стояти») [2, с. 156].

Класична образна опозиція «рідний край - чужий край» у багатьох конформістів і нонконформістів також вибудувана у Шевченковій традиції («Краю милий, моя Україно!» («Розрита могила»)), що чи не першим серед поетів-шістдесятників підтримав Василь Симоненко («Я не бував за дальніми морями»). У Василя Стуса в такому ж ключі читаємо: «О краю мій, коли тобі проститься / крик передсмертний і важка сльоза / розстріляних, замучених, забитих / по соловках, сибірах, магаданах?» («О краю мій, коли тобі проститься...») [10, с. 90], у Тараса Мельничука - «Але якщо немає болю. За край свій - то й життя нема» («Пожити б ще, як хочу... вволю») [6, I, с. 202]. Володимир Забаштанський почав експериментувати 3 творенням нових смислів, у яких зміг висловитися про трагедії України в дев'яностих:

Хоч бідою знов заскочена,

І стоїш напівзчорноблена,

І стоїш напівзмосковщена»

(«Залишися Україною») [1, с. 10].

Хоча, як і в віршах Василя Симоненка, у творах подолянина переважає трансляція непатетичної любові до матері й романтизації рідної землі, совісності до свого національного обов'язку в поєднанні із мотивами «Кобзаря». Саме в таких формах трагічний, забутий поет-офіційник окреслював свою причетність до мовчального спротиву герметистів та голосних акцентів опальних в'язнів сумління. 
Форма поетичного «я» тюремних віршів Василя Стуса й Тараса Мельничука - патріот-жертва, який у межових медитаціях $є$ провідником крізь минуле й сучасне України. В «Отак і вікувати» Василь Стус написав: «Не нарікаю, Боже, / на іспити важкі: / Одним стражденним дрожем / злютовано віки» $[10$, с. 89]; пригадаємо тут-таки поезію Тараса Шевченка «Не нарікаю я на Бога». Знаково, що Юду, зрадників Христа, фарисеїв, апостолів часто згадували Тарас Шевченко, Василь Симоненко, Василь Стус, Тарас Мельничук і Володимир Забаштанський, де поряд, як духовна цитадель та як внутрішня опозиція, - образ України, вільної й мисливої: «Там наша Україна, / котра не знає грат, / а притиску, а кпини, / а помсти - й востократ» («Отак і вікувати», Василь Стус) [10, с. 89].

Супровідним у націонал-патріотичних віршах Василя Стуса («Як добре те, що смерті не боюсь я...»), Тараса Мельничука («Звари мені Вкраїноньку, мати, зрубай мені голівоньку, кате...»), Володимира Забаштанського («Йду з людьми, забуваючи горе і муки...») є мотив самопосвятності, жертви заради України, почасти перейнятий із «Кобзаря»: «Я так ¥ї, я так люблю мою Україну убогу, / що прокляну святого Бога, за неї душу погублю!» («Сон» («Гори мої високії...»)) [12, с. 293]. Щоправда, цей мотив, знову ж таки, чи не найчастіше знаходимо в поезії Василя Симоненка «Задивляюсь у твої зіниці...», у Володимира Забаштанського він увиразнюється у формі символізації віри в українських людей:

В них мільйони є рук - з ними я не безрукий,

В них мільйони очей - з ними я не сліпий [2, с. 97].

Для поетів-дисидентів, чию творчість ми розглядаємо, як і свого часу для ув'язненого Тараса Шевченка, омріяна вільна Україна була художнім двійником реальності, промовистим свідченням $\epsilon$ такі твори: «О, земле втрачена, явися...», «Нема - Вітчизни» (Василь Стус), «Ой на серці світ колючий дріт», «Нема Вкраїни вдома» (Тарас Мельничук); для незрячого Володимира Забаштанського вона була символом всього привільного й ідеального-візуального: «Коло хати, кажуть, білі вишні, / Білі, доле, як у мене 
сни...» («Печія») [2, с.93]. Але у Василя Стуса осмислення українських реалій змінилось із часом з чуттєвого до інтелектуально-екзистенційного, а в табірній ліриці Тараса Мельничука перманентно домінує сентименталізація україніки, трапляються зворушливо-інтимні подробиці: «плачу / хліб мій приріс / до чужого небокраю», «бодай прорости / маками гарячими / на твоїй, Україно, / терновій межі», «тільки небо само / я подумав / це батьківщина / й пішов на дно» [6, II, с. 73].

Стусова Україна бачиться з-за грат як екзистенційний спалах, у різких контрастах: «і собором дзвінким Україна / написалась на мурах тюрми» («На колимськім морозі калина») [9, с. 356], у Тараса Мельничука екзистенційна спазматичність образності спирається на романтичні ідеали: «із неволі йшла моя вітчизна / і собі везла візок із зорями» [6, II, с. 135]. Україна Володимира Забаштанського - підкреслено жіночна й патріархальна водночас:

Україно, молюся за славу,

За твою непокору століть,

За столицю твою златоглаву,

Що по груди в тополях стоїть

$$
\text { («Молитва») [2, с. 6]. }
$$

У Василя Стуса Україна асоціюється з полем синім, як льон, це рідна чужина («У цьому полі синьому, як льон»): «Вистояти. Вистояти. Ні - / стояти. Тільки тут. У цьому полі, / що наче льон. I власної неволі / спізнати тут, на рідній чужині» $[9$, с. 120].

Вірші Василя Стуса, які в зачині, ідеї чи мотиви подібні до відомих християнських молитов, часто наслідують Шевченкові інтонації порівняємо: «Даждь нам, Боже, днесь! Не треба завтра - даждь нам днесь, мій Боже! Даждь нам днесь! («Даждь нам, Боже, днесь!» Василя Стуса) [9, c. 83] та «А всім нам вкупі на землі / Єдиномисліє подай / I братолюбіє пошли» («Молитва» («Злоначинающих спини...») Тараса Шевченка) [12, c. 485]. Відмова від спокус земного життя заради високих ідей є питомою ознакою тюремної поезії, що проявляється спочатку у віршах Тараса 
Шевченка («Не дай спати ходячому, / Серцем замирати / I гнилою / колодою / По світу валятись («Минають дні, минають ночі») [12, с. 253], а потім і в рукописах інакодумців XX століття, з більшою амплітудою українського трагісу, не новозавітньо, а апокаліпсично, як у поезії Василя Стуса «Відійди, сатано, відійди...»: «Відійди, сатано, відійди / віковою стежею недолі, / порозходились босі і голі / і свої загубили сліди... / Відійди, сатано, відійди, / ані застуй свічі молодої. / Ми ізгої, ізгої, ізгої / вікової страшної біди» [10, c.81]. Вражає молитовний дискурс неопублікованої до 2017 р. історіософської ритмізації Тараса Мельничука «Чигрине - сльозо Кобзаря!»: «Нас знищити хочуть! / - іди до Бога / скажи: нас сім мільйонів / виморили голодом / оці циклопи каправі / криваві / а тепер / Чигирине іди до Бога / i проси О Господи / прийди на підмогу / відведи від нас / оцю смерть киплящу / цю пропащу дорогу...» [6, I, с. 136]. Тарас Мельничук збільшує кількість образів тоталітарної безвиході в державі-тюрмі: «людей обнюхують вівчарки, / від огню осліпли журавлі... / А Росія закотилась в чарку / під салют космічних кораблів. («Наступає ніжно на траву...») [6, III, с. 27], «Украли світ... Віщує час погибель неба й вод, / Ламає руки срібний простір...» («Тюремні нари - не гуцульська лавиця») [6, II, с. 53].

Вірші поетів руху опору про долю переобтяжені переосмисленнями філософської детермінанти (обмежень волевиявлення), біблійного тлумачення переходу долиною сліз заради істини, що увиразнив Тарас Шевченко як співець універсальної свободи: «Доле, де ти! Доле, де ти? / Нема ніякої! / Коли доброї жаль, Боже, / То дай злої! Злої!» («Минають дні, минають ночі...») [12, с. 253]. Тому андеграундні вірші $60-80-\mathrm{x}$ років $\mathrm{XX}$ століття подібні до Шевченкового розуміння свободи: «Наша доля вража / нас доріже - нашим ножем» («Костомаров у Саратові» Василя Стуса) [10, с. 92], «I покриткою попідтинню доля / пішла, розп’ята на штики й хрести» («Болить мене доля від дому до Дону» Тараса Мельничука) [6, II, с. 78], «Не пішла б земля водневим димом, / стільки зла зависло над людьми...» («Треба стояти» Володимира Забаштанського) [2, с. 299]. Від «Молитви за Україну» до «Віри в 
людину» Володимир Забаштанський то по-шевченківськи, то посимоненківськи проголошує гуманістичні цінності; порівняємо ідеї творів: «Отче наш, у Твоїм часоплині / Все минає - ридай не ридай. / Прости, Боже, гріхи Україні / I надалі грішити не дай» [2, с.6]; «Віра в рідну твою Батьківщину / Починається з віри в людину» [2, с. 153].

Отже, поезія Т. Шевченка - прототекст для віршів багатьох поетів, які прагнули вивільнення 3-під колоніального пресингу. Саме це й зумовило пророцькі інтонації щодо фіналу земного шляху у версифікаціях поетів руху опору, подібні до інтонацій «І виріс я на чужині...» Тараса Шевченка. Василь Стус у посланні «Як добре те, що смерті не боюсь я...» транслює не власне інфернальну візію, а проголошує християнське духовне воскресіння після перепоховання на рідних теренах:

Народе мій, до тебе я ще верну,

як в смерті обернуся до життя

своїм стражденним і незлим обличчям.

Як син, тобі доземно уклонюсь,

і чесно гляну в чесні твої очі,

і в смерті з рідним краєм поріднюсь

$$
\text { [9, c. 206]. }
$$

Тарас Мельничук не сліпо наслідує «Кобзар», а локалізує в інфернальних ініціаціях за допомогою топоніміки СРСР: «бо шум тайги - це морг» («Ми наречені Колими...») [6, I, с. 102]; український дисидентський апокаліпсис часто оформлений за допомогою дієслів: «Вони оббілують нас до кісток, / До сорочки, / Перестріляють, / Перевішають, / Переб’ють» («Комуністи») [6, I, с. 313]. У Шевченковому ключі, послідовно й притчевопророче підсумовує Володимир Забаштанський: «Знов новою, вольною сім’єю / Треба нам стояти день при дні» («Треба стояти») [2, с. 299].

Василь Стус не менш апокаліпсичний, аніж Тарас Мельничук, зокрема в переосмисленні долі України й Алли Горської як жертви, мисткині- 
українки у присвяті художниці «Ярій, душе. Ярій, а не ридай... »: «...де жменька нас. Малесенька щопта / лише для молитов і сподівання. / Усім нам смерть судилася зарання, / бо калинова кров - така ж крута, / вона така ж терпка, як в наших жилах. / У сивій завірюсі голосінь / ці грона болю, що падуть в глибінь, / безсмертною бідою окошились» [9, с. 83].

Тарас Мельничук i Володимир Забаштанський не вдавалися до версифікаційного переосмислення жіночої жертовності в інтелектуальній боротьбі за свободу й волевиявлення нації, вони перенесли акценти в бік узагальнення жіночої-материнської долі.

Отже, твори поетів руху опору й дисидентів, чия молода муза означена 1960-70-ми роками й пов’язана з Поділлям, себто Василя Стуса, Тараса Мельничука, Володимира Забаштанського, підтверджують, що проблемою для поетів стала насамперед не розбудова мислення нового часу, а реалізація свободи й незалежності крізь призму власних трагедій, доль геніальних класиків і мучеників, зокрема Тараса Шевченка. I хоча Володимир Забаштанський - публіцист-неоромантик, декларативний у своєму письмі, у Василя Стуса переважає інтелектуально-екзистенційна спазматичність, а в Тараса Мельничука - інтуїтивно-підсвідоме відфольклорне образотворення, їхні імпрези закорінені в шевченківських традиціях, їхня творчість сприймається як продовження Шевченкових пророцтв i застережень щодо долі України.

\section{ЛІТЕРАТУРА}

1. Забаштанський В. Найкревніша рідня: Поезії. Київ : Укр. письменник, 1999. 93 с.

2. Забаштанський В. Свічечкою слова: вірші та балади. Жмеринка, 2000. 448 с.

3. Зелененька I. «Чиї це ілюзії стенають плечима, якого народу...»: Тарас Мельничук і літературний процес 60-90-х років в Україні. Вінниця : «Едельвейс і К», 2008. $152 \mathrm{c}$.

4. 3 іменем Кобзаря. Вінничани про Тараса Шевченка / упорядник А. М. Подолинний. Вінниця : Консоль, 2013. 304 с.

5. Крупка В. П. Художній світ Володимира Забаштанського: монографія. Вінниця : ТОВ фірма «Планер», 2014, 228 с.

6. Мельничук T. Твори в 3 томах / упоряд. М. Андрусяк, М. Лазарук. Коломия : Вік, 2003. Т. 1: поезії. 256 с. Т. 2: поезії. 256 с. Т. 3: ч. 1. Вірші. 496 с., ч. 2. Листи, спогади. $344 \mathrm{c}$.

7. Симоненко В. Берег чекань: вірші. Торонто, 2006. 380 с. 
8. Стоголосся. Поетична антологія Вінниччини XX століття / упоряд., вступ. слово, біографічні довідки А. М. Подолинного. Вінниця : Континент-ПРИМ, 2002. 432 с.

9. Стус В. Палімпсести: Вибране. Київ : Факт, 2006. 432 с.

10. Стус B. Твори: у 4-х т. (з дод. 5 і 6 тт.), 9 кн. Львів : ВС «Просвіта», 1994-1999. Т. 1, кн. $1.431 \mathrm{c.}$

11. Ушаков В. Идеи для себя. Современная психология: хрестоматия / под ред. А. Тараса. Минск : Харвест, 2003.

12. Шевченко Т. Кобзар. Київ, 1990. 592 с.

\section{REFERENCES}

1. Zabashtans'kyy, V. (1999). Naykrevnisha ridnya: Poeziyi [The most original family: Poetry]. Kyiv: Ukr. pys'mennyk. [in Ukrainian].

2. Zabashtans'kyy, V. (2000). Svichechkoyu slova: Poeziyi ta baladu [Candle of the word]. Zmerunka [in Ukrainian].

3. Zelenen'ka, I. (2008). "Chyyi tse ilyuziyi stenayut' plechyma, yakoho narodu...”: Taras Mel'nychuk $i$ literaturnyy protses 60-90-kh rokiv v Ukrayini ["Whose illusions are shrugging their shoulders, which people ...": Taras Melnychuk and the literary process of 60-90s in Ukraine]. Vinnytsya: "Edel'veys i K". [in Ukrainian].

4. Z imenem Kobzarya. Vinnychany pro Tarasa Shevchenka (2013) [With the name of Kobzar. Vinnitsyans about Taras Shevchenko]. Vinnytsya: Konsol', 2013. [in Ukrainian].

5. Krupka, V. P. (2014). Khudozhniy svit Volodymyra Zabashtans'koho [The Art World of Vladimir Zabastanskogo]. Vinnytsya: TOV firma "Planer". [in Ukrainian].

6. Mel'nychuk, T. (2003). Tvory v 3 tomakh [Works in 3 volumes]. Kolomyya: Vik. [in Ukrainian].

7. Symonenko, V. (2006). Bereh chekan': virshi [Shoring: poems]. Toronto. [in Ukrainian].

8. Stoholossya. Poetychna antolohiya Vinnychchyny XX stolittya (2002) [Humble. Poetic anthology of Vinnytsia 20th century]. Vinnytsya: Kontynent-PRYM. [in Ukrainian]. Ukrainian].

9. Stus, V. (2006). Palimpsesty: Vybrane [Palimpsesty: Selected]. Kyiv: Fakt. [in

10. Stus, V. (1994 - 1999). Tvory: u 4-kh t. T. 1 [Works: in 4 volumes]. L'viv: VS "Prosvita". [in Ukrainian].

11. Ushakov, V. (2003). Ydey dlya sebya [Ideas for herself]. Sovremennaya psykholohyya: khrestomatyya [Modern psychology: textbook]. Mynsk: Kharvest. [in Russian].

12. Shevchenko, T. (1990). Kobzar [Kobzar]. Kyiv. [in Ukrainian].

\section{АННОТАЦИЯ}

\section{Ирина Зелененькая, Виктор Крупка. Васыль Стус, Тарас Мельничук, Владимир Забаштанский и Шевченков космос Украины}

В статье проанализирован образ-символ Украины в стихах диссидентов Васыля Стуса, Тараса Мельничука и герметиста Владимира Забаштанского. Отчизна находилась в центре художественного мироздания этих лириков - жертв тоталитарного государства, отчасти благодаря своеобразному рыцарскому культу вокруг нее, культивируемому в шестидесятых годах XX столетия. Васыль Стус и Владимир Забаштанский имеют непосредственное отношение к Подолью, Тарас Мельничук отбывал в тюрьме Винницы первый срок. Для этих поэтов тема Украины в осмыслении страдальчества, жертвенности и пророческих озарений Тараса Шевченко стала основной.

Ключевые слова: образ-символ, метафора, экзистенция, герметичность, движение сопротивления, диссиденты. 


\section{ABSTRACT \\ Iryna Zelenenka, Viktor Krupka. Vasyl Stus, Taras Melnychuk, Volodymyr Zabastansky and Shevchenko Space of Ukraine}

The article deals with the image-symbol of Ukraine in the verses of dissidents Vasyl Stus, Taras Melnychuk and Volodymyr Zabashtansky. The fatherland was in the center of the artistic creation of these lyricists, the victims of a totalitarian state, partly due to the kind of knight cult cultivated around it in the sixties. Vasyl Stus and Volodymyr Zabastansky have a direct bearing on Podillya, Taras Melnychuk spent his first term in prison of Vinnytsia. For these poets, the theme of Ukraine in understanding of the suffering, sacrifice and prophetic illusions of Taras Shevchenko became brightleading.

Taras Shevchenko's poetry is a prototype for the poems of many poets who sought liberation from colonial pressure. That is exactly what led to the prophetic intonations concerning the finale of the earth's path in the versification of the poets of resistance movement, similar to the intonations "I grew up in a foreign land ..." by Taras Shevchenko. Vasyl Stus in the message "My Nation, I'll return to you ..." transmits not the actual infernal vision, but proclaims the Christian spiritual resurrection after reburial in his native lands. Taras Melnychuk does not blindly mimic Kobzar, but locates in infernal initiations with the help of the USSR toponymy. Volodymyr Zabastansky summarizes in the form of a parable. Vasyl Stus is no less apocalyptic than Taras Melnychuk, in particular, in redefining the fate of Ukraine and Alla Gorska as a victim, a Ukrainian woman. Taras Melnychuk and Volodymyr Zabastansky did not resort to the revision of the redefinition of women's sacrifice in the intellectual struggle for freedom and the will of the nation, they moved emphasis towards generalization of women's and maternal fate.

The works of poets of the movement of resistance and dissidents, whose young muse was named in the sixties and associated with Podillya, that is, Vasyl Stus, Taras Melnychuk, and Volodymyr Zabastansky, testify that the problem for poets was first not to develop the thinking of the new time, but the realization of freedom and independence through the prism of their own tragedies, the fate of brilliant classics and martyrs, in particular Taras Shevchenko. Although Volodymyr Zabastansky is a publicist neo-romantic, a declarative in his letter, Vasyl Stus dominates intellectually existential spasmism, while in Taras Melnychuk the intuitionalsubconscious folklore, their impressions are rooted in Shevchenko's traditions, their creativity is perceived as an extension of Shevchenko's prophecies and warnings on the fate of Ukraine. dissidents.

Key words: image-symbol, metaphor, existential, tightness, resistance movement, 